\title{
Preserving Bodily Integrity of Deceased Patients From the Novel SARS-CoV-2 Pandemic in West Africa
}

\author{
Peter F. Omonzejele
}

Received: 2 June 2020 / Accepted: 25 September 2020

(C) Journal of Bioethical Inquiry Pty Ltd. 2020

\begin{abstract}
The outbreak of the novel coronavirus pandemic, otherwise known as COVID-19 brought about the use of new terminologies - new lexical items such as social distancing, self-isolation, and lockdown. In developed countries, basic social amenities to support these are taken for granted; this is not the case in West African countries. Instead, those suggested safeguards against contracting COVID-19 have exposed the infrastructural deficit in West African countries. In addition, and more profoundly, these safeguards against the disease have distorted the traditional communityindividuality balance. The enforcement of social distancing, self-isolation, and lockdown has made it impossible for West Africans to drift to their ancestral homes and villages, as is usually the case in times of crisis, with attendant consequences for communal life and traditional burial rites. This could be one of the reasons why some COVID-19 patients are escaping from isolation centres, since to die in such centres violates their bodily integrity at an ontological level.
\end{abstract}

Keywords Community-individuality · Bodilyintegrity $\cdot$ Ontology $\cdot$ SARS-CoV-2 $\cdot$ West Africa

P. F. Omonzejele $(\bowtie)$

Cross-Cultural Bioethics, University of Benin, Benin-City, Nigeria

e-mail: pfomonzejele@yahoo.com

\section{Introduction}

The SARS-CoV-2 (hereafter referred to as COVID-19) pandemic that started in China in December 2019 found its way to West Africa in February 2019. This allowed most West Africans to play the ostrich for about three months as they had thought the virus unlikely to survive in the warm climate of West Africa. It is true, generally, that African countries have recorded fewer cases of COVID-19 than countries in Europe and America. What is not clear at the moment is if a warmer temperature is responsible for the low record of cases or simply a lack of kits for extensive testing. There is no scientific evidence to show that Africans have special immunity against the virus, but at present, Africa presents the least number of confirmed COVID-19 cases compared to America, Asia, and Europe. According to the statistics provided by the European Centre for Disease Prevention and Control (2020), as at June 26, 2020, Africa had accumulated 347,779 confirmed COVID-19 cases, whereas Asia had 2,036,409, America 4,821,970, and Europe 2,365,834. COVID-19 deaths at the same date are Africa 9,069, Asia 51,471, America 238,690, and Europe 189,812 . Perhaps due to the comparatively low death rate, some people in Africa have argued that there was no such thing as COVID-19. They have further opined that what the West refers to as COVID-19 is just a form of acute malaria. This line of thinking might be premised on some similarities of symptoms (such as high temperature and fatigue) associated with both diseases, which in some cases have posed screening challenge (Chanda-Kapata et al., 2020, 151-153). This is 
unlike the case of the Ebola epidemic, which had a distinctive haemorrhagic fever and a high fatality rate.

Despite the scepticism expressed by some people in sub-Saharan Africa about the reality of COVID-19, elementary epistemology teaches that there is a difference between belief and truth. For example, I couldfor whatever reason-choose to believe whatever catches my fancy. This could be true or false. However, truth or facts are independent of my belief and how I feel about something or about the truth of it. Africans will have to face up to the fact that the world is dealing with a virus of a global proportion and so take appropriate steps to deal with it. In fact, most governments in Africa are struggling to address challenges posed by the reality of the pandemic. The COVID-19 pandemic has exposed the general infrastructural deficit in the region, particularly West Africa, as governments in the region grapple to address the challenges it has posed.

\section{Responses and Challenges to the COVID-19 Pandemic in West Africa}

The immediate step taken by most West African leaders was to shut their air and land borders to countries with high incidences of COVID-19. Some people, especially those of the opposition parties, have argued that the decision was taken belatedly. They argued that given the weak health infrastructure in the region, those countries ought to have acted earlier-even before they recorded any incident of the disease, as all primary cases of COVID-19 were imported into the region. Despite those attacks, regional governments took steps to place bans on public gatherings for sporting events and in worship areas, the workplace, and schools. In short, countries in the West African region were shut down. Those preventive steps are similar to those taken by other countries around the world.

The World Health Organization (WHO) suggested several preventive ways to avoid contracting the disease, some of which are regular handwashing with running water and soap, social (physical) distancing, and the use of alcohol-based hand-sanitizers. West African leaders keyed into this and communicated it to their citizens through print and electronic media. However, the challenge is that while some of those measures may appear commonplace and ordinary in Western countries, the same cannot be said for most West African countries where these safeguards may be considered exotic and extraordinary, depending on the density of poverty in that region. The West African "region includes some of the poorest countries in the world ... as nine of the 25 poorest countries are in the region" (Martinez-Alvarez et al. 2020, e631). This means that simple safeguards such as handwashing, hand sanitizers, and so on may prove difficult in many communities. Let us examine the practicality of employing those safeguards.

During the 2014 Ebola epidemic in Western Africa, the challenges associated with regular hand washing with running water were also apparent. Though the WHO has suggested it as one of the most effective ways to prevent contracting the COVID-19 virus, the fact remains that many West African communities do not have access to running water, especially those in rural areas (Omonzejele 2014, 418). According to the World Bank report of 2016 on water and sanitation, over 663 million people lack access to drinking water and about half of those people are in sub-Saharan Africa (World Bank 2016). This means that the suggested use of handwashing against contracting COVID-19 is not practicable for many citizens in the West African region, especially those in rural areas. The alternative, use of hand sanitizers, is also a challenge due to poverty. However, government agencies, corporate bodies and non-governmental organizations have assisted with the production and free distribution of hand-sanitizers and also face masks. It is, however, not clear whether, and to what extent, all rural dwellers benefited from the gesture.

At the level of care for those who have contracted COVID-19, everyone knew, $a b$ initio, it was going to constitute a challenge. Within the first month of managing people for the condition, there were shortages of test kits, ventilators, personal protective equipment, and so on. At some point, the old saying that necessity is the mother of invention came to bear. For instance, in Senegal, with only fifty ventilators nation-wide, scientists in collaboration with Mologic, a British biotech company, "developed a COVID-19 test kit that cost $\$ 1$ and a ventilator which cost $\$ 60$. The kit can deliver results in 10 minutes and can be used at home like a pregnancy kit" (Oguntola 2020). In comparison, imported ventilators cost $\$ 16,000$ each. Nigerian engineers and scientists in tertiary institutions have also reportedly manufactured low-cost ventilators as well. In the meantime, the Chinese government, the European Union business organization, and wealthy individuals have provided assistance in the form of medical 
equipment, technical assistance, and much-needed financial support, among other things, to build standard isolation centres.

However, something unusual has continued to happen in isolation centres in Nigeria and perhaps in other West African countries. Some patients in the isolation centres for COVID-19 management have either escaped or attempted to escape from those centres. Instances of patients escaping from isolation centres are so rampant that Nigeria's Leadership newspaper devoted a special column to it. According to Morphy (2020), in the Nigerian state of Osun, "six persons, who had tested positive for COVID-19, had escaped from the isolation centre without trace." In addition, he reported that in Abuja, the administrative headquarters of Nigeria, "that a lady suspected to be infected with the novel coronavirus allegedly escaped from an isolation centre in Abuja and was reportedly traced and arrested in Akwanga, in Nasarawa State." In a similar vein, "a commercial driver who tested positive to coronavirus in Niger State had reportedly escaped from the isolation centre in Bida." There are several instances that show that these successful and failed attempts to escape from COVID-19 treatment centres are not isolated cases. Escapes and attempts to escape by some patients from those centres have nothing to do with the quality of the isolation centres in Nigeria - which meet WHO standards. Instead, there appear to be deeper reasons for such seemingly "unreasonable" behaviour, as a patient's stay at an isolation centre does not attract any cost to the patient for medical care, nutrition, and general care. What then is the reason? One of the reasons is discoverable in the West African traditional principle of communityindividuality and traditional understanding of bodily integrity for a deceased member of a community.

\section{Bodily Integrity of a Deceased Person Within the Framework of Community-Individuality}

The phrase community-individuality was first used by Iroegbu $(1995,345)$ to describe a way of life which has been in place in traditional African communities since time immemorial. He used the phrase to explain the relationship that exists between the community and the individual in the African context. Speaking from a West African perspective, the human person is understood as a being in communion with others and not as an individual entity. For instance, it would be impossible to define the human person in isolation from that person's relationship with his kindred and ancestral community. A person's life is intertwined with that of his ancestral community, in life and in death, and there are ceremonies and rituals associated with them.

One of the events in the life of the West African is burial rites. A burial rite is contingent upon having a corpse. Corpses of deceased patients from COVID-19 are not recoverable as they are interred by relevant government agencies to curb further transmission of the virus. This is a serious challenge for the West African mind. This is because for the West African, the human body is not a mere container but an entity of intrinsic worth. The intrinsic worth of a person is weaved into those values which are associated with all humans, such as the entitlement for all humans to be treated with respect. But in addition, another-second-layer of intrinsic worth of humans has to do with the specific talents and abilities associated with that individual. On the demise of a person, some of those attributes evaporate with the individual, except for posthumous appreciation of their achievements. The need to dispose of such a body in ceremonial rites is associated with this second level of intrinsic worth. This is the reason a more dignified public burial ceremony (this is different from traditional burial rites) is accorded a deceased prime minister over that of a peasant farmer. However, for the West African, there are other traditional rites associated with the appreciation of a deceased relative, as it is believed that such a deceased has migrated to another phase of life, where they serve as gobetween between the families and communities they left behind and the other world where the deceased now resides. For the West African, this is another level of intrinsic human worth that is only possible after physical death, especially where the deceased was elderly - and the elderly are usually the most susceptible to the COVID-19 virus. It is not any wonder that West Africans spend a lot of money as part of burial rites on a presumably "lifeless" body of a departed one. Based on Tangwa's $(2000,41)$ correct explanation that African themes and traditions are similar in their essentials, I will use the tradition of the Esan people of Nigeria to explain what constitutes traditional burial rites in Western Africa and the implication of its denial. On the death of an elderly man (it could be a woman):

Before the body was ready for burial, it was washed, a new pot being used for the water. If 
the dead man was well-to-do the Egbele demanded the slaughtering of a goat called EBHE IHION in honour in honour of the sponge with which the body had been washed. The body was then wrapped in a new mat and brought to the front of the main building, for the ceremony with EMAN ELINMIN, the special foufou prepared simply with fish, or with goat flesh in the case of a wealthy man. The children assembled round the body that was lying with the head towards the house. On behalf of the first son, one of the IKO EGBELE blessed the dead and cut some of the foufou at the feet. The children and all the descendants knelt beside the body and were given a bit of the food one by one. The body was then placed on a form made with seven fresh mid-ribs of palm branches. The whole corpse is then wrapped with a white piece of cloth provided by the heir. The body is then taken on the head by two men, with the feet in front. They then headed for the cemetery with the heir holding the pot that has been used during the washing. When the body has been interred a pot was placed on the tomb. (Okogie 1994, 173-174)

There are slight variations to burial rites allowing for peculiar circumstances of the dead and communities. Based on some aspects of the burial rites indicated above, it is easy to understand why someone suffering from a potentially fatal disease such as COVID-19 will escape from management centres, as it is common knowledge that bodies of the dead are not given to family members for burial rites. Though the fatality rate is low, the fact still remains that the disease is deadly and has no cure, hence, if contracted, one could die from it, and corpses of the deceased will not be released by the government for traditional burial rites. It is for this reason some people prefer to go to their villages where they resort to the use of local herbs. For them, it is considered a win-win situation. If they are healed from the use of local herbs, then, that is splendid. In the event that they succumbed to the disease, their people despite the contagious nature of the disease must of necessity devise ways to accord them traditional burial rites which will accord such bodies moral and spiritual benefits. This again is a win, for to die without traditional burial rites is inconceivable and abominable.

West Africans believe that the departed is still in communion with the living. This is the third level of intrinsic worth of persons. Hence, it is commonplace to talk of one's ancestors and their spiritual usefulness. But it is impossible to talk of an ancestral being that did not go through the purification of traditional burial rites which accords the deceased with bodily integrity. This means that beyond the body, mind, and soul, the human body on its earthly demise and after burial rites transcends to an ontological level that Mbiti referred to as "the living dead" (Mbiti 1969, 83-275). In similar vein, Gbenda $(2006,7)$ adds that "... the ancestors are believed to be the living-dead ...they were good people in their earthly life and fulfilled societal obligations and duties, they are now spirits." But what qualifies the dead to be an ancestor, that is, "a living-dead"? Oguejiofor $(1996,25)$ provided the response as:

The individual must live a morally upright life. He must also be successful as a person, and his success is shown in his possession of wife (or wives) and children especially male children, and enough material possession. He must have died a good death ... not of mysterious illness or by accident (onwu ekwensu). These conditions must be accompanied by a befitting burial [with which] the dead are received in the land of the spirit (ala ттио) by his ancestors.

This clearly shows that burial rites are central to the ontological transcendence to the level of the "livingdead." This in turn allows for ancestor veneration (Nwanfor 2017, 41-42). These rites cannot be undertaken in the absence of a corpse and so might be responsible for the escape of patients from isolation centres.

\section{Conclusion}

Within the West African context, the community is the placenta through which the individual derives his sustenance and being. But the placenta (the community) is meaningless without the individual it nourishes. In times of crisis, such as the COVID-19 pandemic with no known cure, one simply went back to one's ancestral community to seek remedy or cure for one's condition. In the event the person succumbs to the illness, the person at least receives a befitting burial which accords posthumous bodily respect. This is the most probable reason patients continue to escape from COVID-19 isolation centres. Since this is the most probable case for escapes from isolation centres, governments in the 
West African region should, perhaps, engage with the WHO to seek technical expertise in the decontamination of deceased people from COVID-19 isolation centres, and then make such corpses available to their families for traditional burial rites.

Funding No funding support for the research.

\section{Compliance with ethical standards}

Conflict of interest No conflict of interest.

\section{References}

Chanda-Kapata, P., N. Kapata and A. Zumla. 2020. COVID-19 and malaria: A symptom screening challenge for malaria endemic countries. International Journal of Infectious Diseases 94: 151-153.

Gbenda, J.S. 2006. African religion and Christianity in a changing world. A comparative approach. Enugu: Chuka Educational Publishers.

European Centre for Disease Prevention and Control. 2020. COVID-19 situation update worldwide, as at 26 June 2020. https://www.ecdc.europa.eu/en/geographical-distribution2019-ncov-cases. Accessed June 26, 2020.

Iroegbu, P. 1995. Metaphysics: The Kpim of philosophy. Owerri: International Universities Press.
Martinez-Alvarez, M., A. Jarde, E. Usuf, et al. 2020. COVID-19 pandemic in west Africa. The Lancet Global Health 8(5): e631-e632.

Mbiti, J. 1969. African religions and philosophy. London: Heinemann.

Morphy, R., 2020. Danger! Covid-19 patients are escaping from isolation centres. Leadership, April 28. https://leadership. ng/2020/04/28/danger-covid-19-patients-are-escaping-fromisolation-centres/. Accessed May 2, 2020.

Nwanfor, M.I. 2017. The living-dead (ancestors) among the IgboAfrican people: An interpretation of Catholic sainthood. International Journal of Sociology and Anthropology 9(4): 41-42.

Oguejiofor, J.O. 1996. Eschatology, immortality and Igbo philosophy of life. Bigard Theological Studies 16(2): 25.

Oguntola, T. 2020. Senegal scientists develop \$1 COVID-19 testing kit, \$60 ventilator. Leadership, April. https://leadership.ng/2020/04/28/senegal-scientists-develop1-covid-19-testing-kit-60-ventilator/. Accessed May 2, 2020.

Okogie, C. 1994. Esan native laws and customs with ethnographic studies of the Esan people. Benin: Ilupeju Press.

Omonzejele, P.F. 2014. Ethical challenges posed by the Ebola virus epidemic in West Africa. Journal of Bioethical Inquiry 11(4): 418.

Tangwa, G. 2000. The traditional African perception of a person: Some implications for bioethics. The Hasting Center Report 30(5): 39-43.

World Bank. 2016. Understanding poverty_Water. https://www. worldbank.org/en/topic/water/overview. Accessed May 2, 2020 .

Publisher's note Springer Nature remains neutral with regard to jurisdictional claims in published maps and institutional affiliations. 